\title{
Social Work and Community Care
}




\section{Also by Malcolm Payne}

Power, Authority and Responsibility in Social Services:

Social Work in Area Teams*

Working in Teams*

Social Care in the Community*

Modern Social Work Theory: A Critical Introduction*

Linkages: Effective Networking in Social Care

*Also published by Macmillan 


\section{Social Work and Community Care}

Malcolm Payne

Consultant Editor: Jo Campling 
All rights reserved. No reproduction, copy or transmission of this publication may be made without written permission.

No paragraph of this publication may be reproduced, copied or transmitted save with written permission or in accordance with the provisions of the Copyright, Designs and Patents Act 1988, or under the terms of any licence permitting limited copying issued by the Copyright Licensing Agency, 90 Tottenham Court Road, London W1P 9HE.

Any person who does any unauthorised act in relation to this publication may be liable to criminal prosecution and civil claims for damages.

First published 1995 by

MACMILLAN PRESS LTD

Houndmills, Basingstoke, Hampshire RG21 2XS

and London

Companies and representatives

throughout the world

ISBN 978-0-333-60624-7

ISBN 978-1-349-24013-5 (eBook)

DOI 10.1007/978-1-349-24013-5

A catalogue record for this book is available from the British Library.

$\begin{array}{llllllllll}10 & 9 & 8 & 7 & 6 & 5 & 4 & 3 & 2 & 1\end{array}$

$\begin{array}{llllllllll}04 & 03 & 02 & 01 & 00 & 99 & 98 & 97 & 96 & 95\end{array}$ 
To Anne 


\section{Contents}

List of Figures $\quad \mathrm{xi}$

List of Tables xii

Foreword and Acknowledgements xiii

Client, Consumer, User: A Note on Terminology xv

1 The Social Work Role in Community Care 1

Care management, counselling and social care 3

Outlining policy: Chapters 1 and $2 \quad 6$

The policy meaning of community care 6

'Community' in community care policy 7

The elements of community care policy 10

Long-term care 11

De-institutionalisation $\quad 13$

$\begin{array}{ll}\text { Reducing dependence on public care } & 16\end{array}$

$\begin{array}{ll}\text { Informal care } & 18\end{array}$

Increased participation and choice $\quad 20$

Needs-led services $\quad 22$

Costs 23

Social work skills in community care $\quad 26$

2 The Development of Community Care in the Social Services $\quad 31$

Phases in the development of community care policy $\quad 32$

The institutional phase 33

The commitment phase $\quad 34$

$\begin{array}{ll}\text { The community phase } & 37\end{array}$ 
The rush to reform in the 1980s 40

The individualised phase $\quad 46$

3 Care Management and Social Work 51

American 'case management' 52

Importing case management $\quad 57$

The 'production of welfare approach' 57

The Kent Community Care Project 58

Care in the Community and other PSSRU projects 62

Other related concepts and projects 66

Formalising care management $\quad 69$

Initial application of case management to community care

Care Management in the 'Policy Guidance' $\quad 70$

The 'Care Management and Assessment' guides 74

Introducing care management to community care: $\begin{array}{ll}\text { some conclusions } & 78\end{array}$

Care management and social work $\quad 81$

4 Assessment in Community Care 83

Assessment issues in community care $\quad 83$

Assessment in care management $\quad 89$

$\begin{array}{ll}\text { Screening } & 89\end{array}$

Information and its sources $\quad 92$

Assessment aims $\quad 97$

The assessment process $\quad 99$

Multi-disciplinary assessment 102

Involving the client in assessment 104

Endword 106

5 Care Planning 107

Care plans and the 'Community Care Tariff' 107

Care planning: process and strategy 110

Client's situation $\quad 112$

Examining resources in the client's network 113

Agency context 115

Care planning objectives $\quad 116$

Remaining in or moving into the community 117 
The process of care planning

Skills in care planning - making best use of clients' resources

Enabling

Support

Protection

Informal carers

What is informal care?

Can informal care be made available?

Support for informal care

Skills in care planning - negotiating in clients' networks 138

Negotiation and community care

Negotiating with informal carers

Endword: planning and implementing the plan

\section{Implementing Care Plans}

Community care services

Linking and collaborative work

Official guidance

Teams, teamwork and collaboration

Linking skills

Community work, community social work and community care

Putting it all together

7 Empowerment and Advocacy for Users' Interests

The professional and policy context

Official guidance

Professional context

Clients' rights in social work practice theory 177

Empowerment and advocacy in social work theory 178

Clients' rights, participation and consumerism in social work

Advocacy in related areas of practice

Communication with community care users

Empowerment as part of social work in community care

Complaints and representative machinery 
8 Accountability and Effectiveness in Community Care 198

Accountability issues in community care policy 198

Contracts, regulation and inspection $\quad 200$

Contracts and commissioning 203

Quality assurance $\quad 209$

Inspection and regulation $\quad 212$

Care management monitoring 213

Accountability problems $\quad 215$

9 Policy Development and Training for Community

$\begin{array}{ll}\text { Care } & 217\end{array}$

National policy development $\quad 217$

Local policy development 221

Training 224

Training structures and policy 224

Content and methods: knowledge, skills and values 227

The future for community care 230

Bibliography 235

Name Index 253

Subject Index 258 


\section{List of Figures}

1.1 The three community care roles of social work 2

2.1 Community care relationships 45

3.1 Development of care management concepts 53

4.1 Simple explanatory assessment flowchart 105

5.1 Priorities in service provision and development; the community care tariff 109

5.2 The three community care roles of social work, showing counselling/social work roles in care management and as part of a community care package 111

5.3 Simple network diagram

6.1 The three community care roles of social work, showing elements of the community social work role 146

9.1 Training structures and policies 


\section{List of Tables}

1.1 Types of social care and their role in community care 27

2.1 Phases in the development of community care policy 33

2.2 The development of the 1990 community care reforms 41

3.1 Formulations of the components of American case management and British care management 55

4.1 Information required in social work assessments 94

4.2 Information needs in assessment 96 


\section{Foreword and Acknowledgements}

This book is concerned with the practice consequences of policy developments in community care following the National Health Service and Community Care Act, 1990. Social workers and their managers and policy-makers ought to see practice in the context of policy and organisation, and policy and organisation can only be understood as they are expressed through practice or at least the potential for it. It is unsatisfactory to explore policy without understanding the reality of the practice which will emanate from it. This view, which I hold very strongly, requires a better understanding of practice possibilities and options drawn from professional literature and understanding than we are accustomed to see in policy-oriented books. The corollary, that practice must come from a good understanding of the implementation of policy, is better appreciated. Nevertheless, in the social services of the early 1990 s, policy-analysis related to practice seems to me to have two faults. It is either so critical as to be hostile to the innovation, or it derives from the government's own analysis of its policy, converted into practice and policy guidance and reinforced by selectively funded research. To be helpful, we must be constructively critical of the policy context of practice innovations. Yet we must try to understand what they mean for practice and how they might be implemented, even if at the same time we must be doubtful of their value.

This book also reflects my long-standing commitment to the exploration and understanding of practice. After the publication of the Barclay Report (1982), I wrote a book called Social Care in the Community (Payne, 1986a), in which I tried to analyse and describe the social work skills involved in 'social care planning', which was the Report's term for social work activities contrasted with 'counselling'. Skills such as enabling, negotiating, mobilising resources, 
networking and advocacy are as crucial in social work as the more therapeutic aspect of 'treatment' through counselling-type work, but are much less valued, less realised in accounts of social work practice and less taught than 'counselling'. The interest in anti-discriminatory work in the late 1980s and various advocacy movements have led to a strong development of empowerment and advocacy theory and writing, which was briefly presaged in my 1986 book.

Anxiety about policy issues such as community care plans, resource delegation and organisational and management reform seems to be leading to a neglect of the opportunities of the new community care system for doing more interesting and positive work for neglected groups of clients and their carers. Directors of social services have told me that training must concentrate on budgeting and management rather than on how to help people in the community in more imaginative ways. I hope this is just a characteristic of the setting-up phase of a new policy, but I fear that it reflects a longstanding attitude in the British social services that having good systems of organisation is the only thing needed for good services. Training and research funds so often follow this twisted view of the world, when the creativity of what social workers actually do in relationships with members of the public is just as important for the quality of services, if not more so. It seems that no amount of child care scandals has yet taught us that rigorous procedures, carefully implemented, have to be supplemented by putting sensitive, genuine, creative people into relationships with the public and supporting, training and enabling the use of their skills. To do this, we need a clear understanding of what professional practice can offer in a new policy context. That is what this book is about. It is based on my experience over the last ten years of the voluntary and community sector particularly in Liverpool and Manchester, and my period of development work in mental health with the Richmond Fellowship, and I am very grateful for the ideas and learning that I have gained from the people I have worked with.

I wish to acknowledge the technical help of Kathy Woods, of the Manchester Metropolitan University Computer Services Unit, and help and advice from my teaching colleagues Tony Sargeant and Simon Goodwin, practitioner colleague Jane Dalrymple and the ideas and experience of my 1992 masters class in care management. 